\title{
JUURNAL.RU
}

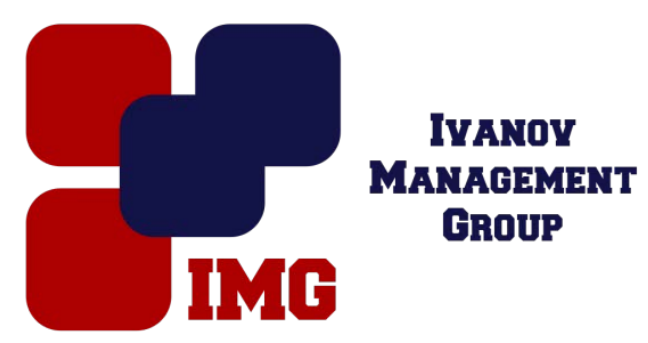

\author{
Смертин Ю.Г. \\ Кубанский государственный университет \\ Краснодар, Россия
}

doi: 10.18411/lj-30-11-2016-1-11

idsp 000001:lj-30-11-2016-1-11

\section{Китайцы в Америке: история эмиграции и адаптации (вторая половина XIX в.)}

\section{Аннотация}

В статье исследуются процессы массовой эмиграции китайцев в Соединенные Штаты Америки во второй половине XIX в., выявляются ее причины и последствия. Особое внимание уделено положению китайских иммигрантов в США, их адаптации и отношениям с местным населением. Автор приходит к выводу, что к началу XX в. Америке сформировались устойчивые социальные общности зарубежных китайцев. Они внесли значительный вклад в местную экономику и культуру, сохраняя при этом разнообразные связи с Китаем.

Ключевые слова: Китай; цинское правительство; эмиграция; США; чайнатаун; тайные общества.

\section{Annotation.}

The article explores the processes of mass emigration of Chinese people to the United States in the second half of the 19th century, identifies its causes and consequences. Special attention is paid to the situation of Chinese immigrants in the United States, their adaptation and relations with the local population. The author concludes that by the beginning of the 20th century America formed the stable social commonality of overseas Chinese. They have made a significant contribution to the local economy and culture, while retaining a variety of ties with China.

Keywords: China; the Qing government; emigration; the United States; chinatown; secret societies.

В середине XIX в. китайское общество находилось в глубоком экономическом, политическом и моральном кризисе. Восстание тайпинов (18511864 гг.) и другие социальные беспорядки, сопровождавшиеся голодовками, вторая опиумная война (1856-1860 гг.) окончательно опустошили и обескровили государство. Десятки миллионов китайцев лишились крова и надежд на будущее. К тому же, остро ощущалась нехватка пахотных земель из-за роста населения, которое к 1850 г. достигло 432 млн. чел.

Одним из ответов на эти вызовы стала эмиграция из Китая в стремлении 
испытать судьбу за морями. Те, кто сделал такой выбор, были в основном выходцами из Юго-Восточного Китая. В основном это были обедневшие крестьяне, не видевшие возможностей для успешной деятельности на родине. Большинство составляли мужчины, многие из них недавно женились и мечтали вернуться разбогатевшими в родные деревни, прикупить земли и изменить безрадостное существование своих семей. Многие из них связывали свои надежды с Соединенными Штатами Америки.

Главным импульсом для китайской иммиграции в США послужила «золотая лихорадка», начавшаяся в 1848 г. в Калифорнии. Кантонские моряки и купцы, побывавшие в Соединенных Штатах, живописали ажиотаж, охвативший американцев в связи с возможностью быстрого обогащения. В основном отправлялись в США выходцы из провинций Гуандун и Фуцзян. Но немногие китайцы успели поработать на прибыльных месторождениях, и большинство после работы на приисках, уже покинутых менее упорными предшественниками, искали другую работу. В условиях интенсивного развития Западного побережья они становились рыночными охранниками, владельцами магазинчиков, работниками прачечных, распространившись по побережью от Лос-Анжелеса до Сиэтла. В 1870 г. почти все прачечные в Сан-Франциско принадлежали китайцам. В 1860-х гг. тысячи китайцев работали на строительстве трансконтинентальной железной дороги из Калифорнии в Юту, где они составляли до 90 \% всей рабочей силы.

После Гражданской войны в США (1861-1865 гг.) южные плантаторы завезли несколько тысяч китайцев в Миссисипи, Алабаму и Теннеси для работы на полях, покинутых освобожденными черными рабами. К концу 1880-х гг. китайцы работали на обувных фабриках Массачусетса, заводах ножевых изделий в Пенсильвании и прачечных Нью-Джерси; в Бостоне сформировалась значительная группа купцов оптовых торговцев. В городах Миссисипи китайцы занялись бакалейной торговлей. Китайские лавки возникали в негритянских кварталах, куда не хотели идти белые купцы.

Процесс адаптации китайских поселенцев в США не был легким. С самого начала американское общество проявило к ним враждебность, а подчас и агрессию. Это было вызвано комплексом причин. Одна из них состояла в том, что многие китайские контрактники не скрывали, что намерены поработать в Америке несколько лет и вернуться домой к своим семьям. Это вело к тому, что китайцев считали «временными жителями», а не иммигрантами, и относились к ним соответственно. Другой причиной было трудолюбие китайцев; им завидовали, так как они могли получать прибыль там, где другие терпели неудачу. С другой стороны, среди белых рабочих общим было убеждение, что китайцы всегда соглашаются работать за меньшую плату, чем другие национальности, и таким образом понижают для всех уровень оплаты труда. В этом утверждении была часть правды, иногда работодатели использовали китайцев в качестве штрейкбрехеров. Плохо зная или не зная вовсе английского языка, китайцы часто не представляли, в каких социальные и экономические конфликты они были втянуты.

Китайцев, или «монголов», как многие белые называли их, не любили или боялись также из-за их странных обычаев. Цинские косички, которые носили многие мужчины, выглядели нелепо в Соединенных Штатах. Американцы замечали огромную разницу в соотношении мужчин и женщин в китайских 
сообществах: в 1880 г. на западе США проживали более 100 тыс. мужчин и только 3 тыс. женщин. Не понимая причины такой диспропорции, многие обвиняли китайцев в гомосексуализме. Вызывали раздражение и непривычные звуки тональной китайской речи, склонность значительной части китайских поселенцев к курению опиума, выпивке, азартным играм, а также их странная и неаппетитная еда.

Раздражала американцев закрытость и обособленность китайских сообществ (фуни). В чайнатаунах были свои клубы, центры социальной помощи, они строили храмы, передавали письма в Китай, переправляли домой тела умерших земляков, стараясь как можно меньше контактировать с властями и окружающим миром. Жилищные и санитарные условия в китайских кварталах Сан-Франциско, ЛосАнджелеса, Портленда, а позднее и Нью-Йорка были пугающе непривычными для местного населения. Все это вместе создавало мнение о порочности, неискренности и неблагонадежности китайцев.

Были и более серьезные обвинения, имевшие под собой определенную почву и приводившие подчас к трагическим последствиям. Китайцев считали преступными элементами, угрозой общественной безопасности. Когда китайские эмигранты прибывали в Сан-Франциско, специальные компании, связанные с китайскими тайными обществами (тунами), объединяли их в группы по принципу диалектной или региональной близости и отправляли в чайнатауны, обещая защиту и покровительство. Туны контролировали торговлю опиумом в США, а также индустрию азартных игр и проституцию, которая приобрела огромные масштабы. Существовало негласное табу на сексуальные отношения между китайскими мужчинами и белыми женщинами; белые проститутки крайне редко соглашались удовлетворять сексуальные потребности «монголов». Тогда туны наладили ввоз китайских девушек из бедных семей, которых родители продавали для работы в качестве прислуги. Их перепродавали во много раз дороже владельцам борделей. Подконтрольные тунам сообщества вовлекались в многочисленные стычки, и даже войны между враждующими бандитскими группировками, что создавало негативную репутацию китайцам в целом.

Иногда трения и неприязнь переходили в открытое насилие, умышленно раздуваемое расистской риторикой белых рабочих и их политических вдохновителей. Самые худшие примеры были в Калифорнии и Вайоминге. В октябре 1871 г., после того как двое полицейских были убиты, пытаясь вмешаться в стычку враждующих тунов, толпа уничтожила чайнатаун в Лос-Анджелесе, грабя магазины, поджигая дома и избивая каждого встреченного китайца. Были убиты 19 китайских мужчин, женщин и детей и ранены сотни, пока, наконец, местные власти не прекратили погромы. 14 лет спустя в Рок-Спрингсе, штат Вайоминг, группа из 150 белых шахтеров-угольщиков, недовольных отказом китайцев участвовать в забастовке, сначала забила лопатами китайского шахтера, затем напала на лагеря китайских рабочих-мигрантов и подожгла 79 зданий. Было убито 28 человек и ранено 15.

Цинское правительство вяло реагировало на все эти эксцессы. Китайские власти всегда рассматривали своих соотечественников, отправившихся за моря по торговым или другим делам (например, в страны Юго-Восточной Азии), как отказавшихся от своей страны, и не проявляли интереса к защите их прав за рубежом. В 1728 г. император Юнчжэн запретил китайцам, покинувшим страну без торговых лицензий, возвращаться на родину. Однако в 1867 г. чиновники 
Ведомства по управлению делами стран (Цзунлиямэнь) наконец обеспокоились проблемами заморских китайцев. Они добились согласия бывшего представителя Авраама Линкольна в Цинской империи ЭнсонаБирлингейма стать китайским послом по особым поручениям. На следующий год Бирлингейм предпринял многочисленные поездки по Соединенным Штатам. Используя свои незаурядные ораторские данные, он убеждал американцев изменить отношение к китайским иммигрантам и к Китаю в целом. «Нынешнее просвещенное правительство Китая непоколебимо движется по пути прогресса», - заявлял он аудитории. «Китай говорит сейчас нам: "присылайте нам вашу пшеницу, ваши пиломатериалы, ваш уголь, ваше серебро, ваши товары - мы возьмем столько, сколько сможем. Взамен мы дадим вам наш чай, наш шелк, нашу рабочую силу, которую мы так широко предоставляем всему миру"». Видимо, для большей убедительности Э. Бирлингейм утверждал, что Цинское государство созрело для обращение в христианство и совсем скоро оно пригласит западных миссионеров «установить сияющий крест на каждой горе и в каждой долине...». Он использовал личные связи с республиканской администрацией и довольно быстро добился результата: в 1868 г. между Китаем и США был подписан договор, гарантировавший соблюдение прав китайских иммигрантов в том же объеме, как и других «граждан государства, пользующегося режимом наибольшего благоприятствования». Также китайское правительство имело право учреждать консульства в портовых городах США. Это был первый равноправный договор между Китаем и западной державой после Опиумных войн. Одним из его последствий стало значительное расширение китайской эмиграции в Соединенные Штаты.

Но действительность мало изменилась, более того, давление на китайцев усилилось. В ходе предвыборной борьбы между демократами и республиканцами постоянно поднималась проблема «желтой опасности» и звучали призывы к ограничению китайской иммиграции. В 1878 г. в Калифорнии был принят закон, по которому наем китайцев на работу считался уголовным преступлением. В 1879 г. президент РатерфордХейс, действуя в духе договора 1868 г., наложил вето на законопроект, предполагавший ограничить число китайских эмигрантов до 15-ти на одном прибывавшем из Китая судне. Однако в 1880 г. Цины были вынуждены согласиться на новый договор, который разрешал Соединенным Штатам «регулировать, ограничивать или временно приостанавливать» поток китайских рабочих, если американское правительство считает такие ограничения «разумными».

В 1882 г. президент Честер Артур решил не накладывать вето на законопроект (ChineseExclusionAct), который «приостанавливал» иммиграцию китайских квалифицированных и неквалифицированных рабочих на 10 лет, обязывал всех китайцев в Соединенных Штатах получить специальные регистрационные сертификаты и запрещал им принимать гражданство США. Запрет на въезд не распространялся на дипломатов, студентов, учителей и туристов. Этот закон положил начало «эпохе исключения» китайцев из экономической и общественной жизни США. В результате число китайских эмигрантов в США стало снижаться: если в 1880 г. их насчитывалось 105 тыс., то в 1900 г. - 90 тыс. Западные штаты пошли гораздо дальше федеральных властей в нарушении основных прав и свободы личности. Так, в Калифорнии в 1885 г. китайским детям запретили посещать общественные школы.

В 1888 г. президент Стивен Кливленд объявил китайцев «элементом, 
игнорирующим нашу конституцию и законы, неспособным к ассимиляции с нашим народом и опасным для нашего мира и благополучия» и подписал закон, запрещавший возвращение китайских рабочих, которые на время уезжали в Китай. $\mathrm{B}$ конце XIX - начале XX в. принимались новые антииммигрантские законы, касавшиеся китайцев. «Эпоха исключения» продолжалась до 1943 г., когда выявилась решающая роль Китая в связывании сил японцев на Тихоокеанском театре военных действий.

«Исключить», вытеснить китайцев из американской действительности, как известно, не удалось. К началу XX в. уже сложилась многочисленная и устойчивая социальная общность, объединенная культурой, взаимной поддержкой, имевшая собственные храмы, школы, газеты, театры, банки. Китайцы США реконструировали традиционный образ жизни и не теряли связи с родиной, отправляя деньги на содержание своих семей. С другой стороны, некоторая часть эмигрантов сумела преодолеть границы чайнатаунов, получить образование и добиться успехов в экономической и интеллектуальной сферах. Похожая ситуация складывалась и в других странах, ставших вторым домом для китайских иммигрантов. Потомки переселенцев первой волны и многочисленные китайцы, присоединившиеся к ним позднее, ныне являются гражданами Канады, Австралии, стран Латинской Америки и Юго-Восточной Азии и вносят заметный вклад в их развитие, сохраняя при этом разнообразные связи с Китаем. 


\section{Литература}

1. Бирюков В., Китайцы в США и американо-китайские отношения на современном этапе. М., 1983. С. 14.

2. Кухаренко Н.В. Китайские этнорелигиозные сообщества в США. Дисс. ... канд. философ. наук. АмГУ, Благовещенск, 2004. С. 31.

3. Лайгнер С.Р. Из истории китайского эмиграционного движения середины XIX - начала XX веков. Дисс. ...канд. ист. наук. М., 1975. С. 114.

4. Нефедов С.А. О демографических циклах в истории Китая (XIV-XIX вв.). URL: http:// book.uraic.ru/elib/authors/nefedov/science/China/China1/htm.

5. Скрозникова В.А. Китайцы США // Расы и народы. 1990. Вып. 20. С. 228.

6. Филиппов С.В. США: иммиграция и гражданство. М.: Наука, 1973. С. 83.

7. CasselS.L. The Chinese in America: A History from Gold Mountain to the New Millenium. Walnut Creek: AltaMira Press, 2002. P. 69.

8. The Chinese Exclusion Act. May 6, 1882. URL: http://www.pbs.org/weta/thewest/resources/archives/seven/chinxact.htm\#act .

9. Chinese Immigration to America. http://library.thinkquest.org/20619/chinese.html.

10. Hunt M. The Making of a Relationship: The United States and China to 1914. N.Y.: Columbia University Press, 1983. P. 92.

11. Lai M.H. Becoming Chinese American. A History of Communities and Institutions. Lanham: AltaMira Press, 2004. P. 224-225, 259.

12. Spence J.D. The Search for Modern China. N.Y.: Norton \& Company. 1990. P. 213.

13. Wei W. The Chinese-American Experience. 1857-1892. URL: http://immigrants.harpweek.com/chineseamericans/1introduction/BillWeiIntro.h tm.

14. Williams F.W. Anson Burlingame and the First Chinese Mission to Foreign Powers. N.Y.: Charles Scribner's sons, 1912. P. 139. URL: www.unz.org/Pub/WilliamsFrederick-1912. 